\title{
Comparing the Financial Performance of Banks in Turkey By Using Promethee Method
}

\section{Füsun Gökalp ${ }^{1}$}

\section{ABSTRACT}

The present study aims to compare the financial performance of state-owned banks, private banks and foreign banks in Turkey for pre-crisis and post-crisis period by using the PROMETHEE (Preference Ranking Organization Method for Enrichment Evaluations) method. In the study, banks are analyzed between 2006 and 2012 years. In order to determine the effects of the recent financial crisis time period is divided into two: pre-crisis period (2006-2008) and post crisis (2009-2012) periods.

In the study 5 main and 12 sub- financial ratios are selected to evaluate the bank performance. The selected ratios are organized into 5 categories (capital, assets, management, earnings and liquidity) in accordance with the CAMEL framework. The deposit banks are ranked based on their financial performance for both before and after the crisis. Research results reveal that state-owned banks were affected significantly by the recent financial crisis. State-owned banks were selected as the best alternative for 2006-2008 period. But for 2009-2012 period state-owned banks went down to the last position whereas the foreign banks went up to first position.

Key Words: Banks, Financial Performance, Financial ratios, PROMETHEE method

\section{INTRODUCTION}

Recent financial crisis has affected the financial systems of many countries. Like other economies the Turkish financial system has been affected by the global crisis. In Turkish financial system, the deposit banks play an important role and contribute substantially to the national economy. The deposit banks determine the distribution of capital and undertake the duty of financial intermediation. Banks give many services to all segments such as firms, government authorities and even each people in a country. These services are crucial for functioning of economy. So the financial performance of the banks affects the national economy substantially. 
The recent financial crisis' effects especially realized in the first half of 2009 in Turkey. Turkey's budget deficit swelled to 23.2 billion Turkish liras in the first half of 2009, 13 times higher than a year earlier. So in 2009, the Turkish Government introduced various economic stimulus measures to reduce the impact of the financial crisis, such as temporary tax cuts on automobiles, home appliances, and housing (Kantar, E, Keskin, M., Deviren, B., 2012). The banks are the most important financial intermediaries in Turkey, and their financial performance has been affected in many ways from the recent financial crisis.

There are some studies tried to evaluate the performance of bank by using multi criteria decision making methods (MCDM). Some of the studies used Analytic Hierarchy Process (Oral and Yolal, 1990, İç, Yurdakul 2000, Ta and Har, 2000, Frei and Harker, 1999, Bayrakdaroğlu and Ege, 2008) for performance evaluation of banks. The other studies such as Seçme and others (2009), Avkıran (2011), Mercan and others (2003) used Technique for Order Preference by Similarity to Ideal Solution (TOPSIS) or Data Envelopment Analysis (DEA) methods to evaluate the performance of banks .

Despite there are some studies that evaluate the performance of Turkish banks with help of multi criteria decision making methods, to our knowledge there is a few studies which measure the performance of the banks in Turkey by using PROMETHEE method. So, the purpose of this study is to extend the researches that use PROMETHEE II multi-criteria approach for performance evaluation. The present study is different from earlier studies in two ways: sample coverage and time-period.

The observation period is 2006-2012. The financial scores are provided from the financial statements of deposit banks in Turkey. In the study the private, state-owned and foreign deposit banks will be ranked due to their financial performance. In the end the performance of this 3 bank group will be compared for pre-crisis and post-crisis period. 
The rest of the paper organized as follows. Section 2 reviews the existing literature about multicriteria bank performance evaluation. Section 3 describes the data and variables used, the methodology applied, and the empirical results. Finally in section 4 the concluding remarks and further research is discussed.

\section{LITERATURE REVIEW}

Many researchers have attempted to measure the performance of banking industry. Beaver (1966) is the first one who used the financial ratios for predicting bankruptcy. Arshadi and Lawrence (1987) measured bank performance using normal correlation analysis. They studied the indexes of profitability, pricing of bank services and loan market share.In addition, Maishanu (2004) identified 8 financial ratios for predicting failure in deposit banks.

There was a considerable number of studies using different Multi-Criteria Decision Making (MCDM) methods such as Analytic Hierarchy Process (AHP), Technique for Order Preference by Similarity to Ideal Solution (TOPSIS) and Data Envelopment Analysis (DEA) for comparing financial performance of banks. Some of them are given below;

Frei and Harker (1999), evaluated the-performance of the banks by using the Analytical hierarchy method. They found a positive relation between process performance and financial performance of the banks.

Cole and Gunther, (1995) rated the performance of individual banks along five key dimensions: capital adequacy, asset quality, management, earnings, and liquidity (CAMEL). Once each of the five areas of performance had been assigned a rating, a composite, or overall, rating was derived, again on a scale from 1 to 5 .

Kosmidou and Zopounidis (2008) used the PROMETHEE method to evaluate the performance of deposit and cooperative banks in Greece for 2003-2004 periods. They selected different financial ratios to evaluate the performance of deposit and cooperative banks. The results obtained indicated 
that deposit banks were tending to increase their account, to attract more customers thereby becoming more competitive.

Ta and Har (2000) employed analytic hierarchy method for selecting the banks according to their performance. In this study financial ratios and non-financial ratios such as customer satisfaction criteria's were used for evaluating the performance of banks.

Avkıran (2011) investigated the efficiency by using DEA method. The empirical analysis in the study was focused on Chinese banks. The study revealed that after tax profit/average total assets and return on average equity were two ratios that best explain the variation.

In Turkey there are also some studies that evaluate the performance of banks by using MCDM. Oral and Yolalan (1990) evaluated the branches of twenty Turkish banks in Turkey. They used financial ratios and data envelopment analysis (DEA) technique to evaluate the branch performance of the banks. The results indicated that most profitable bank branches are the ones that are most effective in service

İç, Yurdakul (2000) developed a credit evaluation model for Turkish banks by using AHP for the banks in their study. In the model they used both qualitative (such as the actual position of the sector they are operating), and quantitative factors. And they expressed a general credit score for each bank with the aid of this performance evaluation model.

Kaya (2001)-made various analyses for Turkish banks with the help of CAMEL (Capital, Asset, Management, Earnings, Liquidity) performing system for 1997-2000 period. Mercan et al. (2003) developed a performance evaluation model with the aid of DEA. Albayrak and Erkut (2005) tried to evaluate the performance of the bank in Turkey. In their study they used analytic hierarchy method. Bayrakdaroğlu and Ege (2008), tried to compare the performance of deposit banks to development and investment banks operating in Turkey with the help of analytic hierarchy process (AHP) for 2001-2006 period. As a result they found that deposit banks showed better performance than development and investment banks. Aysan and Ceyhan (2008) tried to analyze the performance of 
bank industry by using model developed by regression analyses. The results revealed that the efficiency change was negatively related to the number of branches. And they found a positive relationship between bank capitalization and loan ratio with efficiency change.

Seçme and the others (2009) evaluated the performance of largest five banks in Turkey with the aid of TOPSIS and AHP. Dinçer and Görener (2011) evaluated the performance of bank industry in Turkey with both AHP-VIKOR and AHP-TOPSIS. And they compared two different results. With two methods they had the same result. They found that foreign banks had better performance compared to the other bank groups.

Sakarya and Aytekin (2013) tried to compare the financial performance of banks with their performance results obtained from stock returns with the help of PROMETHEE method. They used 10 financial ratios to obtain the financial performance of public-capitalized, private-capitalized and foreign-capitalized deposit banks which were publicly traded.

Uzar (2013) tried to measure the financial performance of public banks in Turkey with the help of PROMETHEE method. He compared the financial performance of public banks for pre-crisis (20022007) period and post crisis (2008-2012) period. The results revealed that global crisis did not affect Turkish public banks directly.

Bağcı and Rençber (2014) tried to compare the public and private banks' performance by using the PROMETHEE method. Research results showed that Halkbank (one of the state-owned bank in Turkey) was the most profitable bank among all state-owned and public banks.

The purpose of this study is to extend the researches about the performance evaluation of the bank industry in Turkey that use PROMETHEE method. The PROMETHEE method is selected because of its simplicity and this method gives an opportunity to select different preference function for all criteria's. 


\section{DATA AND METHODOLOGY}

\subsection{Sample and data}

The sample in this study includes the deposit banks operating in Turkey. Development and Investment banks and Participation banks are not included in the sample. Because these banks have different characteristics and operations compared to deposit banks. Besides, the biggest portion as $\% 90,4$ of the assets of Turkish banking industry belongs to deposit banks as seen in table 1 . So selecting deposit banks as a sample can contribute more to the study.

Table1: Banks in Turkey

\begin{tabular}{|l|l|l|}
\hline Bank Type & Total Assets (million TL) & Sectoral Share (\%) \\
\hline DEPOSIT BANKS & $\mathbf{1 . 5 6 6 . 1 9 7}$ & $\mathbf{9 0 , 4}$ \\
\hline State-owned & 483.378 & 27,9 \\
\hline Private Banks & 842.002 & 48,6 \\
\hline Foreign Banks & 239.948 & 13,9 \\
\hline The Bank Under Saving Deposit and Insurance Fund & 869 & 0,05 \\
\hline DEVELOPMENT AND INVESTMENT BANKS & $\mathbf{7 0 . 1 3 7}$ & $\mathbf{4 , 0}$ \\
\hline PARTICIPATION BANKS & $\mathbf{9 6 . 0 8 6}$ & $\mathbf{5 , 5}$ \\
\hline TOTAL & 1.732 .420 & 100,0 \\
\hline
\end{tabular}

Source: Participation Banks Book, 2013

There are four categories of deposit banks in Turkey. These are; state-owned banks, private banks, foreign banks and Saving Deposit and Insurance Fund (SDIF). Table 2 presents the group shares of deposit banks in Turkey based on total assets. Private deposit banks' assets constitute 53,1\% of all deposit banks', state-owned follow private deposit banks by a share of 30,9\% of total assets. Even if they are larger in number than other private and state-owned deposit banks, foreign banks' asset shares are smaller (16\%). SDIF has the smallest share in the deposit bank group as $0,1 \%$. 
Table 2: Deposit Banks' Group Shares in Turkey

\begin{tabular}{|l|l|l|}
\hline & Number & Total Assets (\%) \\
\hline Deposit Banks & $\mathbf{3 2}$ & $\mathbf{1 0 0 , 0}$ \\
\hline State-owned Banks & 3 & 30,9 \\
\hline Private Banks & 11 & 53,1 \\
\hline The Bank Under Saving Deposit & & 0,1 \\
(SDIF) & 1 & 16,0 \\
\hline Foreign Banks & 17 & \\
\hline
\end{tabular}

Source: Banking Association of Turkey, 2013

The sample of the study consists of state-owned, private and foreign deposit banks that operate in Turkey. The bank under Saving Deposit and Insurance Fund (SDIF) is not taken as a sample because SDIF is not an actively operating bank. SDIF was founded in order to contribute the confidence and the stability of banking industry. The banks which have serious problems were transferred to SDIF. It resolves the banks and assets transferred to it in the most proper way.

Financial ratios of the banks are taken from the Turkish Bankers' Association web site. 2006- 2012 is chosen as an observation period.

\section{Variables}

The variables of the study are financial ratios. The values of selected ratios are collected from the Turkish Bankers’ Association web site.

The financial ratios are selected based on CAMEL framework. CAMEL framework is widely used in the evaluation of banking performance. CAMEL rating system was first developed by federal regulators in USA at early 1970's. CAMEL framework is divided along five key dimensions: capital adequacy, asset quality, management, earnings, and liquidity (Wirnkar and Tanko, 2008) Key dimensions can be summarized as below; (Sakarya, 2010:14-16; Kandemir and Arıc1, 2013:65) 
- Capital adequacy: In this variable the banks' capital adequacy is evaluated. When evaluating the capital adequacy of the banks, executives consider these factors; the level of the capital, ability to find additional capital in case of emergency, distribution of asset structure, the level of provision for risks and the level of the equity

Asset Quality: The most important issue for the asset quality is the quality of the credits. The most important risk is non-performing loans. Also slow payers may be a potential risk.

- Management Quality: This concept denotes the capacity of management. If the managers have the capability to state, evaluate and control the risk, management quality will be high.

- $\quad$ Earnings: This concept emphasizes the profitability of the bank. The survival of the banks depends on their ability to increase their profitability.

- Liquidity: One of the most important risks of the banks is liquidity risk. Liquidity denotes the ability of finding funds, the consistency of the deposits and the ability to cover the short-term liability.

Table (3) illustrates the selected ratios which are categorized on CAMEL framework. 12 financial ratios are selected. The financial ratios and their weights are identified with the help of literature (Kaya (2001); Çinko ve Avcı (2008); Ertuğrul ve Karakaşoğlu (2008) ;Kosmidou, Zopounidis (2008) ). In the table also the preference of the ratio is seen which shows whether the criterion has to be minimized or maximized. For example profitability ratios are preferred to be maximized whereas loan ratios are preferred to be minimized. 
Table 3. EvaluationVariables

\begin{tabular}{|c|c|c|c|c|}
\hline & Notation & $\begin{array}{l}\text { Preferences } \\
\text { (Min/Max) }\end{array}$ & $\begin{array}{l}\text { Weight of } \\
\text { Sub Ratio }\end{array}$ & $\begin{array}{l}\text { Weights with Respect } \\
\text { to Main Ratios } \\
\text { C,A,M,E,L) }\end{array}$ \\
\hline Capital Adequacy (C) & & & $\mathbf{0 , 3 0}$ & \\
\hline $\begin{array}{l}\text { 1. Capital Adequacy Ratio } \\
\text { ((Capital Adequacy Required For } \\
\text { Credit, Operational and Market } \\
\text { Risk }) * 12,5) * 100\end{array}$ & $\mathrm{C} 1$ & Max & 0,60 & 0,18 \\
\hline 2. Equity/Total Asset & $\mathrm{C} 2$ & Max & 0,40 & 0,12 \\
\hline Asset Quality (A) & & & 0,20 & \\
\hline $\begin{array}{l}\text { 3.Non performing Loans(net)/Total } \\
\text { Credits }\end{array}$ & A1 & $\min$ & 0,60 & 0,12 \\
\hline Real Assets /total Assets & A2 & $\min$ & 0,40 & 0,08 \\
\hline Management Quality (M) & & & 0,15 & \\
\hline Staff Costs/Total Assets & M1 & $\min$ & 0,30 & 0,045 \\
\hline Operating Costs/Total Assets & M2 & $\min$ & 0,35 & 0,0525 \\
\hline Net Income/Branches & M3 & $\max$ & 0,35 & 0,0525 \\
\hline Earnings (E) & & & 0,15 & \\
\hline Net Income/Total Assets & E1 & $\max$ & 0,35 & 0,0525 \\
\hline Net Income/Equity & E2 & $\max$ & 0,35 & 0,0525 \\
\hline Income Before Tax/Total Assets & E3 & $\max$ & 0,30 & 0,045 \\
\hline Liquidity (L) & & & $\mathbf{0 , 2 0}$ & \\
\hline Liquid Assets/Total Assets & L1 & $\max$ & 0,50 & 0,1 \\
\hline Liquid Assets/Short-term Liability & L2 & $\max$ & 0,5 & 0,1 \\
\hline
\end{tabular}




\subsection{Methodology}

The financial performance of state-owned, private and foreign deposit banks is evaluated by using PROMETHEE method.

The PROMETHEE method was first developed by Professor Jean-Pierre Brans in 1982. Since then, this method is used to solve the problems in different areas. But it is not widely used in finance problems especially in Turkey. With this study it is hoped to make the use of this method more widespread.

In the literature, there are numerous studies which compare different MCDM methods. Some of them highlights that PROMETHEE has clear advantages over other MCDM methods. For example, Gilliams et al. (2005) noted that PROMETHEE II was preferable to ELECTRE III and AHP under four different criteria such as user friendliness, simplicity, variation of the solution, and implementation. Moreover, Al-Shemmeri et al. (1997) pointed out that the PROMETHEE method was easier to be understood by the decision-maker compared with Electre III.

Several versions of the PROMETHEE methods such as the PROMETHEE I for partial ranking of the alternatives from best to the worst, the PROMETHEE II for complete ranking of the alternatives from best to the worst, the PROMETHEE III for using interval data and the PROMETHEE V for selecting a subset of alternatives using linear programming, have been developed for dealing with sorting problems. In this study, we are dealing with the complete ranking of the banks form best to the worst. So the PROMETHEE II method is selected.

PROMETHEE II method consists of five basic stages (Brans and Vincke (1985):

(1) Identifying data matrix based on pair-wise comparisons.

(2) Defining the preference function (6 different type of preference function exist) 
Beans and Vincke (1985) proposed six types of preference functions to facilitate the selection. These preference functions are (1) usual (2) U-shape (3) V-shape c (4) Level (5)Linear (6) Gaussian Among them, the Gaussian preference function is often used in practice for performance evaluation of banks (Uzar (2013), Komidou, Zopounidis (2008), Doumpos, Zopounidis (2009), Bağc1, Rençber(2014). Gaussian will be selected when you want to prefer criteria according to deviation from mean values. In this study Gaussian preference function is selected.

(3) Calculating the global preference index.

$\pi(a, b)=\sum_{k=1}^{q} P_{k}(a, b) \cdot w_{k}$

This index gives a measure of the preference of a over $b$ for all criteria: the closer to 1 , the greater the preference. $\mathrm{W}_{\mathrm{k}}$ represents the weight of criterion $\mathrm{P}_{\mathrm{k}}$. It is assumed that $\mathrm{w}_{\mathrm{k}} \geq 0$ and $\sum_{k=1}^{\mathrm{q}} \mathrm{w}_{\mathrm{k}}=1$.

(4) Calculation of partial ranking. In order to compare each criterion with respect to all the other criteria-s, two scores are computed:

$\Phi^{+}(\mathrm{a})=\sum \Pi(\mathrm{a}, \mathrm{b})$

$\mathrm{b} \in \mathrm{A}$

$\Phi^{-}(\mathrm{a})=\sum \Pi(\mathrm{b}, \mathrm{a})$

$b \in A$

The positive preference flow $\Phi+(a)$ denotes the positive outranking while the negative preference flow $\Phi-(a)$ denotes the negative outranking for each alternative, respectively. The PROMETHEE I is a partial ranking (Brans and Vincke, 1985)

(5) Calculation of complete outranking (PROMETHEE II)

$\Phi(\mathrm{a})=\Phi^{+}(\mathrm{a})-\Phi^{-}(\mathrm{a})$ 
$\Phi($ a) denotes the complete outranking for each alternative. The Promethee II complete ranking is obtained by ordering the actions according to $\Phi(\mathrm{a})$ (net flow). The higher the net flow the better the alternative (Brans and Vincke, 1985).

\subsection{Analysis}

The sample in this study includes the deposit banks operating in Turkey. Deposit banks are divided into three groups which are state-owned banks, private banks and foreign banks.

In this study twelve key financial ratios are selected covering all aspects of CAMEL framework. These ratios are; Capital Adequacy Ratio (C1), Equity/Total Assets (C2), Non-performing loans(net)/ Total credits (A1), Real assets/Total assets(A2), Staff costs/Total assets (M1), Operating costs/Total assets (M2), Net income/Branches (M3), Net income/Total assets (E1), Net income/Equity (E2), Income before tax/Total assets (E3), Liquid assets/Total assets (L1), Liquid Assets/Short-term liability (L2). The data used in the study have been collected from the Turkish Bankers' Association web site (www.tbb.org.tr).

According to the level of importance, weights of the ratios are identified. Gaussian preference function is selected for this study. 2006- 2012 period is chosen. Time period is divided into two; 2006-2008 and 2009-2012 periods. These two periods will give us opportunity to compare the bank performance before and after the crisis. 2008 is an important year for recent financial crisis, which originated in USA, because after 2008 financial crisis started to influence all over the world.

Table 4 shows the decision matrix used for performance evaluation of Turkish deposit banks. And the financial ratios for 2006-2008 and 2009-2012 period ; 
Table 4: Decision Matrix for Performance Evaluation of Deposit Banks (Average for 2006-2008 and 2009-2012 Period)

\begin{tabular}{|c|c|c|c|c|c|c|c|c|c|c|c|c|}
\hline Criteria & $\mathrm{C} 1$ & $\mathrm{C} 2$ & A1 & $\mathrm{A} 2$ & M1 & M2 & M3 & E1 & E2 & E3 & L1 & $\mathrm{L} 2$ \\
\hline Weight & 0,18 & 0,12 & 0,12 & 0,08 & 0,045 & 0,0525 & 0,0525 & 0,0525 & 0,0525 & 0,045 & 0,1 & 0,1 \\
\hline Preference Function & $\begin{array}{l}\text { Type } \\
6\end{array}$ & $\begin{array}{l}\text { Type } \\
6\end{array}$ & $\begin{array}{l}\text { Type } \\
6\end{array}$ & $\begin{array}{l}\text { Type } \\
6\end{array}$ & $\begin{array}{l}\text { Type } \\
6\end{array}$ & $\begin{array}{l}\text { Type } \\
6\end{array}$ & $\begin{array}{l}\text { Type } \\
6\end{array}$ & $\begin{array}{l}\text { Type } \\
6\end{array}$ & $\begin{array}{l}\text { Type } \\
6\end{array}$ & $\begin{array}{l}\text { Type } \\
6\end{array}$ & $\begin{array}{l}\text { Type } \\
6\end{array}$ & $\begin{array}{l}\text { Type } \\
6\end{array}$ \\
\hline Min/Max & $\max$ & $\max$ & $\min$ & $\min$ & $\min$ & $\min$ & $\max$ & $\max$ & $\max$ & $\max$ & $\max$ & $\max$ \\
\hline \multicolumn{13}{|c|}{ Financial Ratios For 2006-2008 Period } \\
\hline State-Owned Banks & 21,90 & 9,66 & 0,26 & 2,29 & 1,10 & 2,04 & 1,80 & 2,40 & 25 & 3,10 & 37 & 60 \\
\hline Private Banks & 17,00 & 11,20 & 0,53 & 4,97 & 1,30 & 3,14 & 1,60 & 2,00 & 18 & 2,50 & 34 & 55 \\
\hline Foreign Banks & 15,70 & 12,60 & 0,61 & 3,28 & 2,10 & 4,67 & 1,00 & 1,90 & 15 & 2,40 & 32 & 54 \\
\hline \multicolumn{13}{|c|}{ Financial Ratios For 2009-2012 Period } \\
\hline State-Owned Banks & 16,70 & 9,86 & 0,51 & 2,15 & 0,90 & 1,90 & 2,30 & 2,10 & 21,00 & 2,60 & 30 & 45 \\
\hline Private Banks & 17,60 & 12,90 & 0,54 & 3,83 & 1,10 & 2,50 & 2,30 & 2,10 & 16,00 & 2,60 & 33 & 56 \\
\hline Foreign Banks & 17,70 & 13,40 & 1,43 & 3,07 & 1,80 & 4,00 & 1,10 & 1,60 & 12,00 & 1,90 & 34 & 63 \\
\hline
\end{tabular}

In order to rank deposit banks with the help of PROMETHEE II, the Visual Promethee Academic Software is used.

\subsection{Results}

The complete ranking results of banks are presented in table 5. The overall net flows are shown for each period (2006-2008 and 2009-2012) and for each bank group.

Table5. Complete Ranking of Deposit Banks For 2006-2008 Period and 2009-2012 Period

\begin{tabular}{|l|l|l|l|l|}
\hline Banks & $\begin{array}{l}\text { Net Flow For } \\
\mathbf{( 2 0 0 6 - 2 0 0 8} \text { Period) }\end{array}$ & Rank & Net Flow For & Rank \\
\hline State-Owned Banks & 0,3311 & 1 & $-0,1458$ & 3 \\
\hline Private Banks & $-0,1322$ & 2 & 0,0447 & 2 \\
\hline Foreign Banks & $-0,1989$ & 3 & 0,101 & 1 \\
\hline
\end{tabular}


The ranking results according to banks' financial performance, showed us that state-owned banks were selected as the best alternative based on the results of PROMETHEE II for 2006- 2008 period and the others respectively private banks and foreign banks. But for 2009-2012 period ranking results changed and foreign banks went up to first position whereas state-owned banks went down to last position. Private Banks retained the same ranking for 2009-2012 periods.

These results showed us that financial crisis might have affected the financial performance of stateowned deposit banks. Their Phi score dropped down. But the Phi scores of private and foreign banks increased so the ranking changed for post-crisis period. In order to understand what differs for each bank group before and after the crisis, detailed reports must be evaluated. Detailed reports are available in the Visual PROMETHEE Academic Software .One of these detailed reports is PROMETHEE Rainbow.

Figure 1 and Figure 2 illustrates PROMETHEE Rainbow which are a disaggregated view of the PROMETHEE II complete ranking. Figures are measure of each bank groups' power or weaknesses compared to the other bank group for each period.

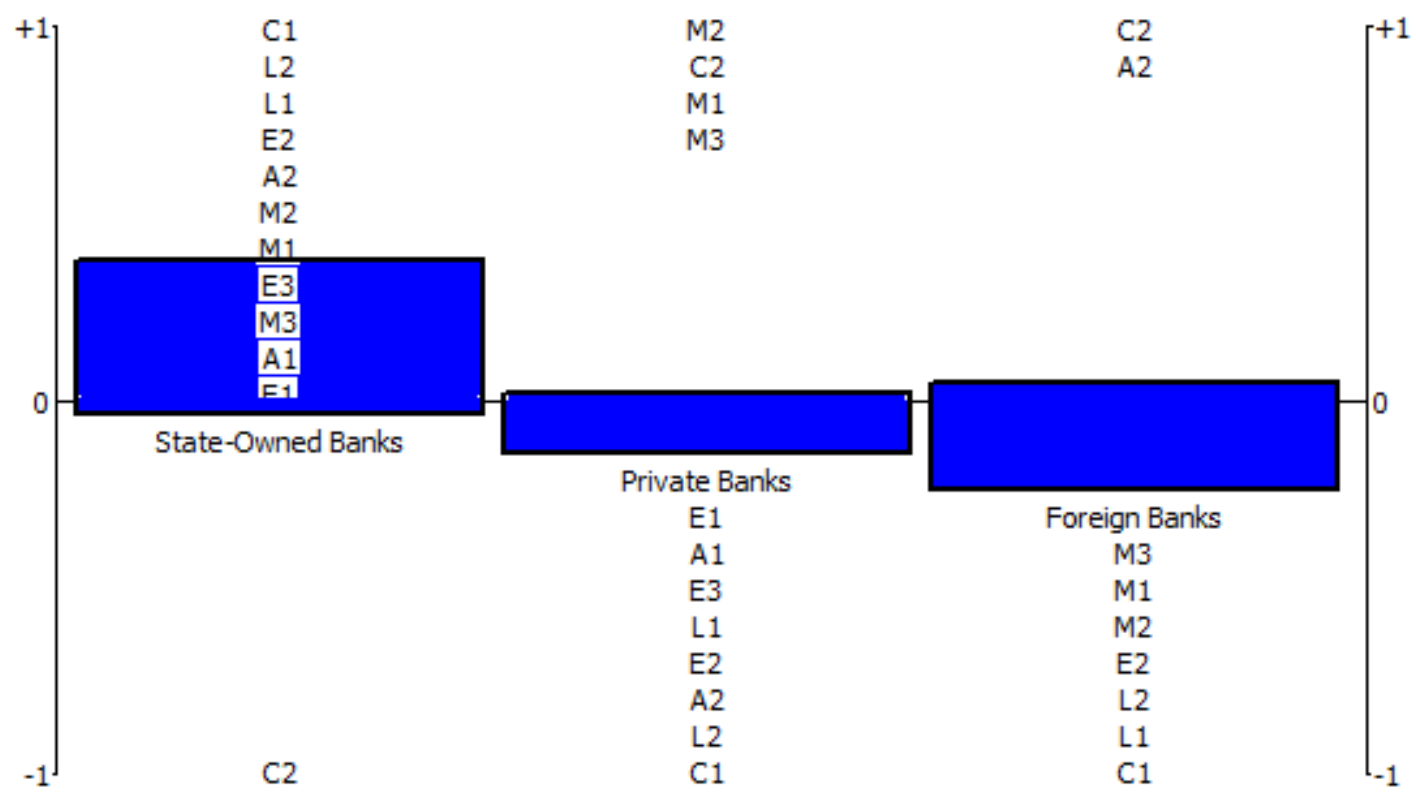

Figure 1. PROMETHEE Rainbow for 2006-2008 Period 


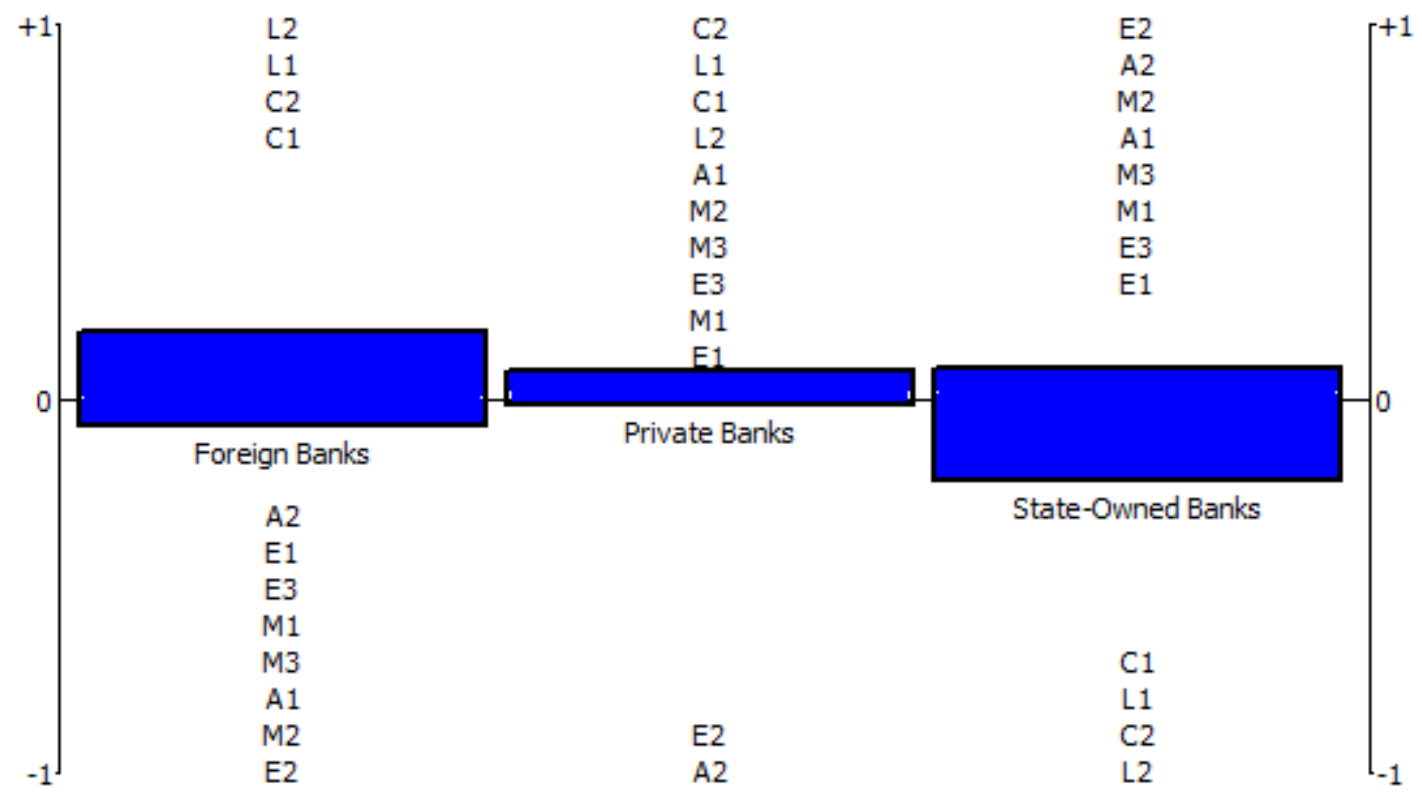

Figure 2. PROMETHEE Rainbow for 2009-2012 Period.

In figures bank groups are displayed from left to right according to the PROMETHEE II ranking. Each slice shows financial ratios' net flow for each bank group.

- State owned banks exhibited no negative slices for 2006-2008 period as all financial ratios contributed positively to its financial performance. And state-owned banks were ranked first for 2006-2008 period. But for 2009-2012 period state-owned banks had bad capital adequacy ratio, equity/total asset ratio, liquid asset/total asset ratio and liquid assets/short-term liability ratio. Finally, the negative slice is more than the positive ones for 2009-2012 period so the Phi score is negative. So state-owned banks' ranking went down to the last position.

- Private Banks retained the same ranking for each period; 2006-2008 and 2009-2012 period. But the phi score increased to 0,0447 from -0,1322. Private Banks had much more a mixed performance combination. Some ratios were good some ratios were bad for each period. Some ratios were improved for 2009-2012 period. These ratios are capital adequacy ratio, nonperforming loans 
(net)/total credits ratio, net income/total assets ratio, income before tax/total assets, liquid assets/total assets ratio and liquid assets/short-term liability ratio. The performance of private banks were quite average.

- Foreign banks were in the last position for 2006-2008 period whereas went up to the first position for 2009-2012 period. Foreign banks also had a mixed performance combination. Some ratios were good some ratios were bad for each period. For 2006-2008 period the negative slice was more than the positive ones so the Phi score is $-0,1989$. But for 2009-2012 the positive slice was more than the negative ones and the Phi score was 0,101. The financial performance of foreign banks improved for post-crisis period. Especially, foreign banks have a very good capital adequacy ratio, equity/total asset ratio, liquid asset/total asset ratio and liquid assets/short-term liability ratio for post-crisis period contrary to state-owned banks.

\section{CONCLUSION}

Bank performance is gaining more interest after the financial crisis. This paper presents a PROMETHEE method for providing a comprehensive support for performance evaluation of banks. In addition to that in the paper the performance of deposit banks compared for before the crisis and after the crisis.

To be able to understand if there are differences between the ranking of deposit banks for pre-crisis and post-crisis, the time period was divided in to two; 2006-2008 and 2009-2012 period. The results showed that ranking of banks based on their financial performance were affected from the recent financial crisis. State-owned banks were selected as the best alternative for 2006-2008 period. But for 2009-2012 period ranking results changed; state-owned banks went down to the last position whereas the foreign banks went up to first position.

The results indicated that the crisis affected the foreign banks' ranking positively. In contrast the ranking of state-owned banks was affected negatively from the crisis. The major advantage of foreign banks laid in their power at capital adequacy and liquidity ratios with respect to other bank 
groups. There was a clear distinction at these ratios. Foreign banks had better capital adequacy and liquidity ratios than state-owned banks. Our results corroborated the findings of Cornett and others (2010). Cornett and others (2010) compared the performance of private and state-owned banks before and after the Asian crisis. The present study differed from Cornett and others (2010) in two ways: sample coverage and time-period. But both study examined the performance of state-owned and private banks before and after the crisis period. Cornett and others (2010) found that deterioration in the cash flow returns (liquidity), core capital and credit quality (capital adequacy) of state-owned banks were significantly greater than private banks. Cornett and others (2010) explained this situation with the perverse incentives of the manager and political bureaucrats and intervention of government to state-owned banks. Our results also corroborated the findings of Dinç (2005). Dinç (2005) stated the reason for worse performance of state-owned banks after the crisis period that stateowned banks tended to finance private projects that are too large or unprofitable to enhance social welfare. And also Dinç (2005) stated that the government was involved heavily in the banking system. Besides, the reason of the worse capital adequacy and worse liquidity performance of stateowned banks after the crisis may be foreign banks' capability to find easier capital and financial aid from their parent company.

In the study it is shown that PROMETHEE method offers decision makers detailed reports for analyzing the financial position of enterprises. These reports give insights to finance executives in understanding advantages and disadvantages of their enterprise. Finally we can conclude that PROMETHEE methodology and its detailed reports can be used by financial experts as supportive tools for performance evaluation of banks in daily lives. 


\section{REFERENCES}

Albayrak, Y. E., Erkut, H (2005) 'Banka Performans Değerlendirmede Analitik Hiyerarşi Süreç Yaklaşımı ’ İTÜ Dergisi/D Mühendislik, 4, (6): 47-58.

Al-Shemmeri T., Al-Kloub, B., Pearman, A. (1997) 'Model choice in multicriteria decision aid', European Journal of Operational Research, 97 : 550-560.

Arshadi, N., E.C. Lawrence (1987) 'An Empirical Investigation of New Bank Performance' Journal of Banking and Finace, 11: 33-48.

Avkıran (2011) 'Association of DEA super-effiency estimates with financial ratios: Investigating the case of Chinese bank' Omegai, 39(3): 323-334

Aysan, A.F. and Ceyhan S.P. (2008) 'What Determines The Banking Sector Performance in Globalized Financial Markets? The Case of Turkey' Physica A, 387:1593-1602

The Banks Association of Turkey, www.tbb.org.tr

Bayrakdaroğlu, A. and Ege, İ. (2008) 'Türkiye'deki Bankaların Performansının Analitik Hiyerarşi Süreci ile Değerlendirilmesi Üzerine Bir Model Önerisi' TÜIK- 17. Ístatistik Araştırma Sempozyumu Bildiriler Kitabr: 32-49

Bağcı H., Rençber, Ö.F. 'Kamu Bankaları ve Halka Açık Özel Bankaların Promethee Yöntemi İle Karlı1ıklarının Analizi', Aksaray Üniversitesi, İBF Dergisi, 6(1), 39-47

Beaver, W. (1966) 'Financial Ratios as Predictors of Failure' Journal of Accounting Research, 4: 71111, Retrieved from: http://www.jstor.org/stable/2490171

Brans J. P. and Vincke PH. (1985) 'A Preference Ranking Organisation Method (The PROMETHEE Method for Multiple Criteria Decision-Making)' Management Science, 31(6): 647656

Cole, R.and Gunther, J. (1995), 'A CAMEL Rating's Shelf Life': Retrieved from: http://ssrn.com/abstract=1293504 Cornett M.M. , Guo L, Khaksari S., Tehranian H.,'The impact of state ownership on performance differencesin privately-owned versus state-owned banks: An international comparison', Journal of Financial of Intermediation , 19:74-94.

Çinko, Murat; AVCI, Emin; (2008) 'CAMELS Derecelendirme Sistemi ve Türk Ticari Bankacılık Sektöründe Başarısızlık Tahmini, Bankacılık ve Finansal Piyasalar Dergisi’ BDDK, 2(.2): 25-49

Dinç, S., (2005). 'Politicians and banks: political influences on government-owned banks in emerging markets’, J.ournal of Financial Economics, 77:453-479.

Dinçer, Hasan, Görener, Ali (2011) 'Performans Değerlendirilmesinde AHP_VIKOR - TOPSIS Yaklaşımları: Hizemt Sektöründe Bir Uygulma’ Mühendislik ve Fen Bilimleri Dergisi Sigma, 29: 244-260

Doumpos, M., Zopounidis, C. (2009), 'A Multicriteria Approach to Bank Rating', European Working Group Multiple Criteria Decision Aiding, 3(19):17-19 
Ertuğrul, İrfan and KARAKAŞOĞLU, Nilsen (2008) 'Banka Şube Performanslarının VIKOR Yöntemi İle Değerlendirilmesi’ Endüstri Mühendisliği Dergisi, 20(1): 19-28.

Frei, F. X. and Harker, P.T., (1999) 'Measuring Aggregate Process Performance Using AHP' European Journal Of Operational Research, 116: 436-442.

Gilliams, S, Raymaekers,D., Orshoven,V (2005), "Comparing multiple criteria decision methods to extend a geographical information system on afforestation", Computers and Electronics in Agriculture, $49: 142-158$.

Ignatius, J. , Behzadian, M., Malekan, H.S., Latiha, D(2012).,'Financial Performance of İran's Automotive Sector Based on Promethee II, Proceedings of the 2012 IEEE ICMIT: 35-38.

İç, Y. T., Yurdakul, M.(2000) 'Analitik Hiyerarşi Süreci (AHS) Yöntemini Kullanan Bir Kredi Değerlendirme Sistemi’ Gazi Üniv. Müh. Mim. Fakültesi Dergisi, 15(1): 1-14.

Kantar, E.; Keskin, M; Deviren, B. (2012). 'Analysis of the effects of the global financial crisis on the Turkish economy, using hierarchical methods'. Physica A, 391: 2342-2352.

Kaya, Yasemin Türker (2001) 'Türk Bankacılık Sektöründe CAMELS Analizi, Bankacılık Düzenleme ve Denetleme Kurumu’ MSPD Çalışma Raporları, 2001/6: 1-20.

Kosmidou,K, C. Zopounidis (2008) 'Measurement of Bank Performance in Greece', South-Eeastern Europe Journal of Economics: 79-95.

Maishanu, M. (2004) 'A Univariate Approach to Predicting Failure in the Commercial Banking SubSector in Nigerian' Journal of Accounting Research, 1(1), Retrieved from: https://www.academia.edu/260074/A_UNIVARIATE_APPROACH_TO_PREDICTING_FAILURE_IN_COMMERCIAL_BANKING_SUB-SECTOR Mercan, M., Reisman, A., Yolalan, R. and Emel, A. B.(2003) 'The Effect of Scale and Mode of Ownership on The Financial Performance of Turkish Banking Sector: Result of a DEA-Based Analysis' Socio-Economic Planning Sciences, 37(3): 185-202.

Oral, M., Yolalan, R. (1990) ‘ An Emprical Study On Mesauring Efficiency And Profitably Of Bank Branches, Ring Efficiency And Profitably Of Bank Branches' European Journal Of Operational Resarch, $46: 282-294$

Participation Banks Book, 2013, http://www.tkbb.org.tr/images/Documents/TKBB.pdf (23.10.2014) Sakarya, Aytekin (2013) 'İMKB'de İşlem Gören Mevduat Bankalarının Performansları ile Hisse Senedi Getirileri Arasındaki İlişkinin Ölçülmesi: PROMETHEE Çok Kriterli Karar Verme Yöntemiyle Bir Uygulama', Uluslararası Alanya İsletme Fakültesi Dergisi, 5(2): 99-109.

Seçme, N.Y., Bayrakdaroğlu, A. and Kahraman, C.(2009) 'Fuzzy performance evaluation in Turkish Banking Sector Using Analytic Hierarchy Process and TOPSIS' Expert Systems with Applications, 36(9):11699-11709.

Ta, H. P. and Har K. Y. (2000) 'A Study of Bank Selection Decisions in Singapore using the Analytical Hierarchy Process’ International Journal of Bank Marketing, 18 (4): 170 - 180. 
Uzar (2013) 'Financial Performance Test of Public Banks in Turkey: An Application of PROMETHEE,' International Journal of Economics and Finance Studies, 5 (2), ISSN: 1309-8055 Wirnkar A.D. and Tanko M. (2008) 'CAMEL(S) and Bank Performance Evaluation: The Way Forward' http://papers.ssrn.com/sol3/papers.cfm?abstract_id=1150968 (28.10.2014) 